\title{
Coexistence of Deficiencies of Uroporphyrinogen III Synthase and Decarboxylase in a Patient with Congenital Erythropoietic Porphyria and in His Family
}

\author{
Anne G. Freesemann ${ }^{1}$, Klaus Hofweber ${ }^{2}$ and Manfred O. Doss ${ }^{1}$ \\ 1 Abteilung für Klinische Biochemie, Fachbereich Humanmedizin und Klinikum der Philipps-Universität, \\ Marburg, Germany \\ ${ }^{2}$ Kinderkrankenhaus St. Marien, Landshut, Germany
}

Summary: A hitherto undescribed dual deficiency of uroporphyrinogen III synthase and uroporphyrinogen decarboxylase was observed in the erythrocytes in a 14 year-old patient who had presented with congenital erythropoietic porphyria since early childhood. Whereas congenital erythropoietic porphyria was metabolically and clinically overt, a hereditary deficiency of uroporphyrinogen decarboxylase was confirmed by family study. The uroporphyrinogen III synthase activity of the propositus was decreased to $26 \%$ of the control while his asymptomatic family members had activities between $53-65 \%$ of the control. Additionally, the uroporphyrinogen decarboxylase activity was $55-66 \%$ of the control in the patient and his family. Family investigations have shown that the two disorders do not consistently segregate together. Although urinary porphyrin excretions of relatives were in the physiological range, the proportion of coproporphyrin isomer I showed a relative increase, which can serve as a biochemical indicator for heterozygous uroporphyrinogen III synthase gene carriers.

\section{Introduction}

Porphyrias are mainly hereditary diseases, each one reflecting a partial genetic defect of one of the enzymes in the haem biosynthetic pathway (1). Simultaneous presence of the enzyme deficiencies of two types of hereditary porphyria in one individual and/or in the same family is characteristic of dual porphyrias. These conditions are rare, and have so far been reported only as combinations of acute intermittent porphyria and porphyria variegata, known as the Chester Type (McKusick 176010) (2), acute intermittent porphyria (McKusick 176000) and porphyria cutanea tarda (McKusick 176100) $(3,4)$, porphyria variegata (McKusick 176200) and porphyria cutanea tarda $(5-8)$, and hereditary coproporphyria (McKusick 121300 ) with congenital erythropoietic porphyria (McKusick 163700) (9) (fig. 1).

This present report describes a patient with congenital erythropoietic porphyria who was also found to have coincidentally inherited half-normal activity of uroporphyrinogen decarboxylase ${ }^{1}$ ).

\footnotetext{
1) Enzymes

Porphobilinogen synthase (EC 4.2.1.24)

Porphobilinogen deaminase (EC 4.3.1.8)

Uroporphyrinogen III synthase (EC 4.2.1.75)

Uroporphyrinogen decarboxylase (EC 4.1.1.37)
}

\section{Patient and Methods}

The male patient, born in 1981, developed excessive haemolytic anaemia as a newborn. Photosensitivity became obvious after phototherapy which was indicated because of severe jaundice. Blistering occurred on foot, stomach, chest and forehead, and the healed areas were hypopigmented. Additionally, red coloured urine was observed. Family members were clinically unaffected. During the subsequent years the clinical symptoms of congenital erythropoietic porphyria seen in the patient exacerbated and were accompanied by development of severe osteoporosis, renal and liver siderosis and nephrotic syndrome (10). Further porphyrin studies were performed in 1995.

Porphyrins were determined by high performance thin-layer chromatography in combination with absorption spectrophotometry (11). Urinary and faecal coproporphyrin isomers I/III were analysed as free acids by $\mathrm{C}_{8}$ reversed phase high performance liquid chromatography in connection with fluorometric detection (12). Porphobilinogen synthase, porphobilinogen deaminase and uroporphyrinogen decarboxylase activities were determined as previously described $(3,14,15)$. Uroporphyrinogen III synthase activity in red cell lysates was determined by a coupled enzyme assay adapted from Tsai et al. (16) with slight modifications. Incubation was carried out at $37^{\circ} \mathrm{C}$ for $15 \mathrm{~min}$ in the dark. The reaction was stopped by the addition of $500 \mu$ l trichloroacetic acid containing iodine and riboflavin. The latter served as an internal standard. The oxidized uroporphyrin isomers were separated by $\mathrm{C}_{18}$ reversed-phase HPLC (RP 18 LiChroCART $^{\circledR} 4 \cdot 70$ $\mathrm{mm}$, Merck, Darmstadt, Germany) and quantitated by fluorometric detection.

\section{Results}

The first pathobiochemical investigation of the patient at the age of 24 days showed elevated porphyrin levels in urine, faeces and blood. Metabolic data are compiled 


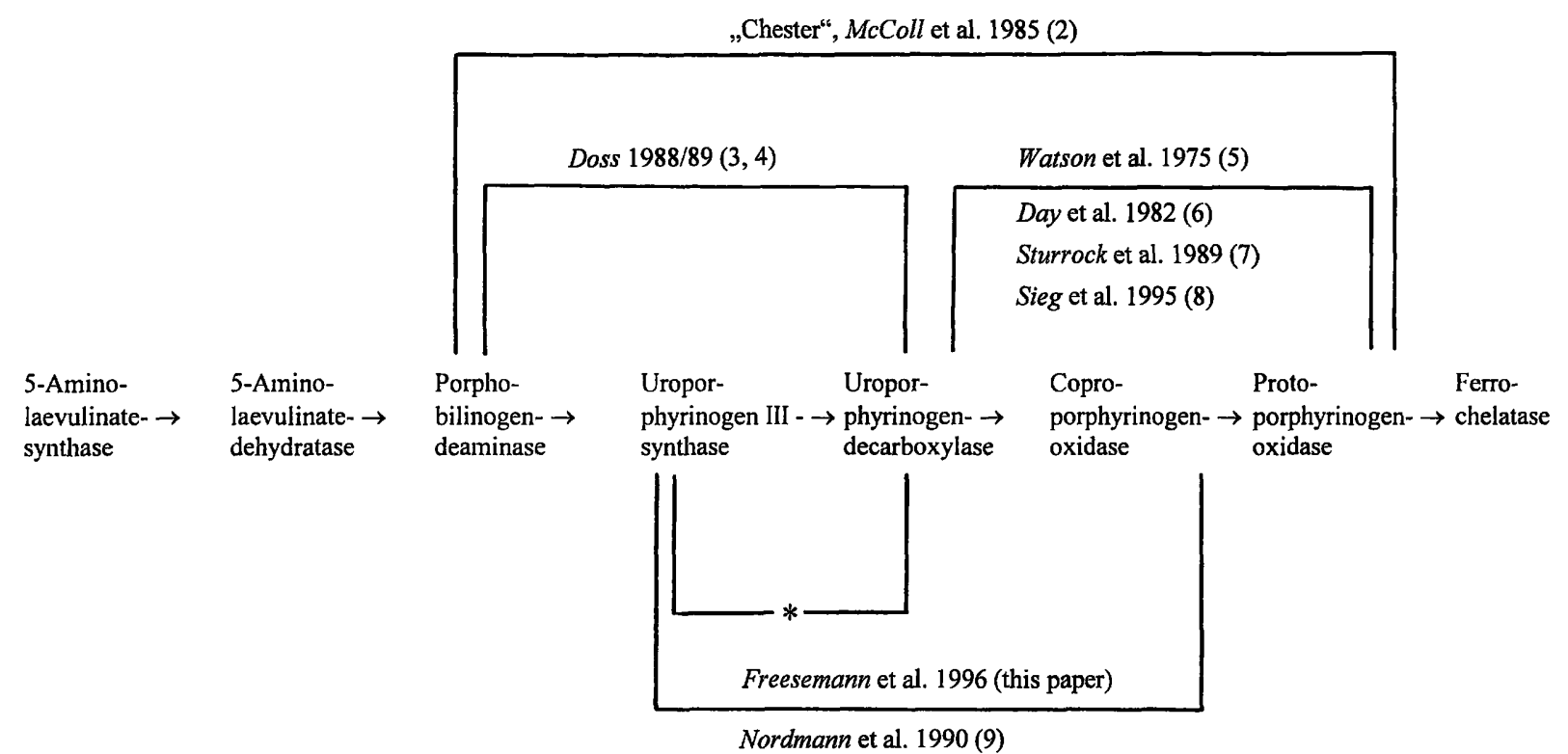

Fig. 1 All the known dual porphyrias and the corresponding defective enzymes in haem biosynthesis (* indicates the dual enzyme deficiency reported in this paper).

in table 1 and 2. Urinary porphyrins consisted mostly of uro- and coproporphyrins, while the predominant faecal porphyrin was coproporphyrin; in each case there was a high predominance of isomer I. These characteristic constellations confirmed the clinical suspicion of congenital erythropoietic prophyria. We found a decreased activity of uroprophyrinogen decarboxylase in erythrocytes, which is not typical of congenital erythropoietic porphyria. We therefore performed metabolic and enzyme studies on both the patient and his parents. Porphyrinaemia and porphyrinuria were exacerbated with clear predominance of uroprophyrin in urine and blood. Enzyme studies again showed a reduced activity of uroporphyrinogen decarboxylase $(60 \%$ of control) and revealed a dual deficiency with decreased activity of both uroporphyrinogen III synthase ( $26 \%$ of control), as seen in congenital erythropoietic porphyria, and uroporphyrinogen decarboxylase, as seen in porphyria cutanea tarda (tab. 3).

His parents had decreased uroporphyrinogen III synthase activities at an intermediate level (around $60 \%$ of control) and, notably, both parents also showed decreased activity of uroporphyrinogen decarboxylase (tab. 3), i.e. both parents were double heterozygotes (fig. 2). Red cell porphobilinogen synthase and deaminase activities were normal in the patient and his family (data not shown). No significant increases in porphyrins were found in urine, faeces or blood of family members. However, the urinary coproporphyrins of family members showed an increase in the isomeric series I (tab. 1). His sister was also found to be doubly heterozygous for the trait of congenital erythropoietic porphyria and porphyria cutanea tarda, as shown by enzyme activities and a slight increase in the proportion of urinary coproporphyrin I (tabs. 1 and 3).

\section{Discussion}

A male child with a hitherto undescribed double enzyme deficiency of uroporphyrinogen III synthase and uroporphyrinogen III decarboxylase, associated with the clinical feature of congenital erythropoietic porphyria, is presented. His parents were found to be heterozygous for both the trait of congenital erythropoietic porphyria and the trait of porphyria cutanea tarda. Therefore, the

I

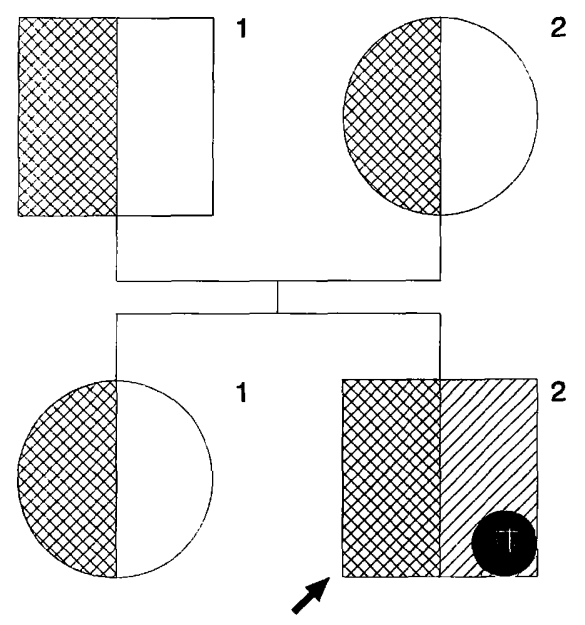

Fig. 2 Pedigree of family with dual enzyme deficiency.

heterozygous deficient of uroporphyrinogen III synthase and uroporphyrinogen decarboxylase activities, heterozygous deficient of uroporphyrinogen decarboxylase activity and homozygous deficient of uroporphyrinogen III synthase activity, - clinical manifestation of congenital erythropoietic porphyria; $\nearrow$ propositus. 


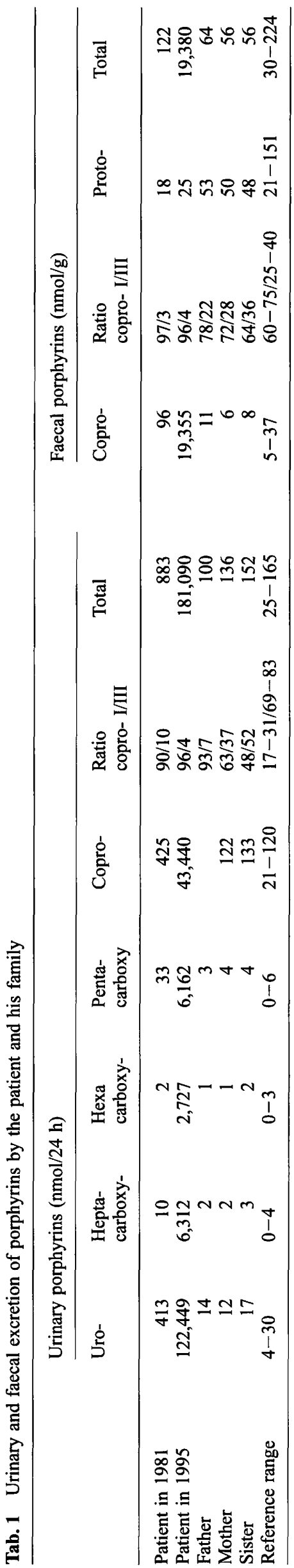

uroporphyrinogen decarboxylase deficiency of the patient was inherited. Low erythrocyte uroporphyrinogen decarboxylase activity is observed in porphyria cutanea tarda type II, the familiar type $(1,17)$. The genes encoding uroporphyrinogen III synthase and uroporphyrinogen III decarboxylase are located on different chromosomes. The human congenital erythropoietic porphyria gene has been mapped to chromosome 10 q25.2 $-\mathrm{q} 26 \cdot 3(18-21)$. The gene for uroporphyrinogen decarboxylase has been assigned to the region 1 pter-p34 of the human chromosome 1 (17). This suggests that this case of dual enzyme deficiency results from the incidental genetic transmission of two independently occurring gene defects, as confirmed by the family investigation (tab. 3). The patient received a uroporphyrinogen III synthase gene defect from each parent and a uroporphyrinogen decarboxylase gene defect from only one parent (fig. 2). From this it can be concluded that these two defects do not segregate together. Hepatoerythropoietic porphyria, the homozygote form of porphyria cutanea tarda, can be excluded by the enzymatic and metabolic data given before.

The propositus developed the clinical syndrome of congenital erythropoietic porphyria shortly after birth. Coinheritance of uroporphyrinogen decarboxylase deficiency does not appear to have modified the phenotype of congenital erythropoietic porphyria. Whereas congenital erythropoietic porphyria follows an autosomal recessive trait of inheritance, genetically determined porphyria cutanea tarda follows an autosomal dominant trait of inheritance, though with a low clinical penetrance. Lack of modification of the phenotype by uroporphyrinogen decarboxylase deficiency is not unexpected, since in most of those known to have inherited this deficiency it is clinically and metabolically latent (17). Furthermore congenital erythropoietic porphyria and porphyria cutanea tarda are both porphyrin accumulation disorders in which skin photosensitivity and chronic photodermatosis are main clinical symptoms $(22,23)$. Cutaneous symptoms of congenital erythropoietic porphyria are much more severe than those of porphyria cutanea tarda; in addition, porphyria cutanea tarda usually becomes clinically overt in adult life $(1,24)$. Therefore, the clinical consequences of the uroporphyrinogen decarboxylase gene defect would be covered by the clinical features of congenital erythropoietic porphyria.

The porphyrin metabolite pattern of the patient reflected uroporphyrinogen III synthase deficiency. A slight metabolic expression of uroporphyrinogen decarboxylase deficiency became obvious from the higher proportion $(1: 0.3)$ of urinary uroporphyrin, in comparison with other congenital erythropoietic porphyria cases $(1: 0.6$; $\mathrm{n}=7$ ). Additionally, reinvestigation after 14 years revealed an increase in the proportion of uroporphyrin from $47 \%$ to $68 \%$ of total urinary porphyrins. 
Tab. 2 Blood porphyrin profiles of the family

\begin{tabular}{|c|c|c|c|c|c|c|c|c|}
\hline & \multicolumn{5}{|c|}{ Plasma porphyrins (nmol/1) } & \multicolumn{3}{|c|}{ Erythrocyte porphyrins (nmol/1) } \\
\hline & Uro- & $\begin{array}{l}\text { Hepta- } \\
\text { carboxy- }\end{array}$ & Copro- & Proto- & Total & Uro- & Proto- & Total \\
\hline Patient in 1981 & 432 & 13 & 581 & 18 & 1058 & 61 & 2065 & 2126 \\
\hline Patient in 1995 & 4,032 & 229 & 1,438 & 140 & 6,191 & 11,724 & 5,162 & 16,886 \\
\hline Father & 2 & 1 & 0.5 & 14 & 18 & 1 & 267 & 269 \\
\hline Mother & 1 & 1 & 1 & 12 & 15 & 1 & 249 & 250 \\
\hline Sister & 1 & 0.5 & 1 & 11 & 14 & 1 & 338 & 340 \\
\hline Reference range & $0-1$ & $0-1$ & $0-3$ & $0-15$ & $0-19$ & $0-1$ & $90-640$ & $90-670$ \\
\hline
\end{tabular}

Tab. 3 Enzyme activities in the erythrocytes of the patient and his relatives (cf. pedigree in fig. 2) in $\%$ of control

\begin{tabular}{|c|c|c|c|c|c|}
\hline Enzyme & $\begin{array}{l}I_{1} \\
\text { Father }\end{array}$ & $\begin{array}{l}\mathrm{I}_{2} \\
\text { Mother }\end{array}$ & $\begin{array}{l}\mathrm{II}_{1} \\
\text { Sister }\end{array}$ & $\begin{array}{l}\mathrm{II}_{2} \\
\text { Patient }\end{array}$ & $\begin{array}{l}\text { Reference range } \\
\text { (nkat/l) } \\
{[\overline{\mathrm{x}} \pm \mathrm{SD}(\mathrm{n})]}\end{array}$ \\
\hline Porphobilinogen deaminase & 74 & 97 & 93 & 83 & $22 \pm 3(68)$ \\
\hline Uroporphyrinogen III synthase & 65 & 59 & 53 & 26 & $702 \pm 62(10)$ \\
\hline Uroporphyrinogen decarboxylase & 57 & 55 & 66 & 60 & $2.8 \pm 0.4(35)$ \\
\hline
\end{tabular}

The uroporphyrinogen III synthase deficiency is clinically overt in the homozygous state, but clinically silent in the heterozygous condition. Total porphyrin excretion as well as urinary uro- and coproporphyrin excretion of the gene carriers (parents and sister) were normal. However, the relative increase of coproporphyrin isomer I indicates intermediate uroporphyrinogen III synthase deficiency. This isomer III/I inversion is a metabolically intriguing sign and can serve as a biochemical indicator of heterozygotes. Uroporphyrinogen decarboxylase deficiency is clinically silent in family members. Urinary uro- and heptacarboxyporphyrin excretion are normal, indicating that, at the time of investigation, the disposition for porphyria cutanea tarda was in the genetic phase without metabolic consequences (22). All types of porphyria cutanea tarda can be triggered by liver diseases, alcohol and oestrogens (1). Obviously, the parents were not exposed to such triggering factors. The observation that a porphyria cutanea tarda gene carrier can show a decreased enzyme activity without metabolic and clinical consequences is well known $(17,25)$.

This combination of congenital erythropoietic porphyria and hereditary coproporphyria (9), is also the second report of a dual enzyme deficiency in which one disorder is autosomal recessive and the other is autosomal dominant.

\section{Acknowledgements}

This study was supported by the Hans-Fischer-Gesellschaft, $\mathrm{Mu}-$ nich and by the Deutsche Forschungsgemeinschaft, Bonn, Germany. The skilful technical assistance of Mrs. S. Preis, H. Schudarek and $M$. Wenz is gratefully acknowledged.

\section{References}

1. Kappas A, Sassa S, Galbraith RA, Nordmann Y. The porphyrias. In: Scriver CR, Beaudet AL, Sly WS, Valle D, editors. The metabolic and molecular basis of inherited disease. 7th ed New York: McGraw-Hill, 1995:2103-51.

2. McColl KEL, Thompson GG, Moore MR, Goldberg A, Church SE, Quadiri MR, Youngs GR. Chester porphyria. Lancet $1985 ; 2: 796-9$.

3. Doss M. New dual form of porphyria. Lancet 1988: 1:945-6.

4. Doss MO. Dual porphyria in double heterozygotes with porphobilinogen deaminase and uroporphyrinogen decarboxylase deficiencies. Clin Gen 1989; 35:146-51.

5. Watson CJ, Cardinal RA, Bossenmaier I, Petryka ZJ. Porphyria variegata and porphyria cutanea tarda in siblings: chemical and genetic aspects. Proc Natl Acad Sci USA 1975; 72:5126-9.

6. Day RS, Eales L, Meissner D. Coexistent variegate porphyria and porphyria cutanea tarda. N Engl J Med 1982, $307: 36-41$

7. Sturrock ED, Meissner PN, Maeder DL. Kirsch RE. Uroporphyrinogen decarboxylase and protoporphyrinogen oxidase in dual porphyria. S Afr Med J 1989; 76:405-8.

8. Sieg I, Bhutani LK, Doss MO. Dual porphyria of coexisting variegata and cutanea tarda. Eur J Clin Chem Clin Biochem 1995; 33:405-10.

9. Nordmann Y, Amram D, Deybach JC, Phung LN, Lesbros D. Coexistent hereditary coproporphyria and congenital erythropoietic porphyria (Günther disease). J Inher Metab Dis 1990; 13:687-91.

10. Lange B, Hofweber K, Waldherr R, Schärer K. Congenital erythropoietic porphyria associated with nephrotic syndrome and renal siderosis. Acta Pädiatr 1995: 84:1325-8.

11. Doss M. Porphyrins and porphyrin precursors. In: Curtius HC, Roth M, editors. Clinical biochemistry. Principles and methods. Vol II. New York: De Gruyter, 1974:1325-71.

12. Sieg I, Doss MO. HPLC der Koproporphyrin-I/III-Isomere bei hepatischen Porphyrinopathien. Lab Med 1992; 16:89-96. 
13. Sieg I, Doss MO, Kandels H, Schneider J. Effect of alcohol on $\delta$-aminolevulinic acid dehydratase and porphyrin metabolism in men. Clin Chim Acta 1992; 202:211-8.

14. Doss MO, von Tiepermann R. Uroporphyrinogen-Synthase in Erythrozyten bei akuter intermittierender Porphyrie: Neue pathobiochemische Aspekte. J Clin Chem Clin Biochem 1978; 16:111-8.

15. von Tiepermann R, Koss G, Doss M. Uroporphyrinogen decarboxylase deficiency in experimental chronic hepatic porphyria Hoppe Seyler's Z Physiol Chem 1989; 361:1217-22.

16. Tsai S, Bishop D, Desnick R. Coupled-enzyme and direct assay for uroporphyrinogen III synthase activity in human erythrocytes and cultured lymphoblasts. Anal Biochem 1987; 166:120-33.

17. Elder GH. Molecular genetics of disorder of haem biosynthesis. J Clin Pathol 1993; 46:977-81.

18. Tsai SF, Bishop D, Desnick R. Human uroporphyrinogen III synthase: molecular cloning, nucleotide sequence and expression of full-length cDNA. Proc Natl Acad Sci USA 1988; 85:7049-53.

19. Deybach JC, de Verneuil H, Boulechfar S, Grandschamp B, Nordmann Y. Point mutations in the uroporphyrinogen III synthase gene in congenital erythropoietic porphyria (Günther's disease). Blood 1990; 8:1763-5.

20. Warner CA, Yoo HW, Tsai SF, Roberts AG, Desnick RJ. Congenital erythropoietic porphyria: characterization of the genomic structure and identification of mutations in the uroporphy- rinogen III synthase gene. Am J Hum Genet 1990; 47 (Suppl), 321A.

21. Astrin KH, Warner CA, Yoo HW, Goodfellow PJ, Tsai SF, Desnick RJ. Regional assignment of the human uroporphyrinogen III synthase (UROS) gene to chromosome 10q25.2q.26.3. Hum Genet 1991; 87:18-22.

22. Doss MO, Sassa S. The porphyrias. In: Noe DA, Rock RC, editors. Laboratory medicine. The selection and interpretation of clinical laboratory studies. Baltimore, Maryland, USA: Williams \& Williams, 1993:535-53.

23. Nordmann Y, Deybach JC. Congenital erythropoietic porphyria. Sem Dermatol 1986; 5:106-14.

24. de Verneuil H, Moreau-Gaudry F, Ged C, Bensidhoum M Hombrados I, Tricoire J, Rolland M. Porphyrie érythropöétique congénitale. À propos d'un cas fatal en periode néonatal dû à une hémolyse aiguë avec insuffisance hépatique. Arch Pédiatr 1995; 2:755-61.

25. Lehr PA, Doss M. Chronische hepatische Porphyrie mit Uroporphyrinogen-Decarboxylase-Defekt in vier Generationen. Dtsch Med Wochenschr 1981; 106:241-5.

\section{Received July 9/October 7. 1996}

Corresponding author: Professor Dr. Manfred O. Doss, Abteilung für Klinische Biochemie, Fachbereich Humanmedizin, Klinikum der Philipps-Universität, Deutschhausstraße 171/2, D-35037 Marburg, Germany 
